\title{
Mass spectrometry of aromatic cyclic imides and amides. Part II: electron ionization induced decomposition of $N$-substituted 3,4-pyridinedicarboximides
}

\author{
María M. Blanco, Alejandra Salerno, and Isabel A. Perillo* \\ Department of Organic Chemistry, Faculty of Pharmacy and Biochemistry, \\ University of Buenos Aires, Junín 956 (1113), Buenos Aires, Argentina \\ E-mail: iperillo@ffyb.uba.ar
}

\begin{abstract}
The behaviour of a series of $N$-substituted 3,4-pyridinedicarboximides under electron impact at 70 $\mathrm{eV}$ is analyzed. Compounds under study were divided into three groups: 3,4pyridinedicarboximidoacetic, $\quad \beta$-3,4-pyridinedicarboximidopropionic $\quad$ and $\gamma$-3,4pyridinedicarboximidobutyric acid derivatives (compounds 1, 2 and $\mathbf{3}$ respectively), which in turn determine the dominant fragmentations. The proposed fragmentation patterns are supported by HRMS and tandem mass spectrometry. Results are in some cases compared to data from the related 2,3-pyridinedicarboximides 4.
\end{abstract}

Keywords: Electron ionization mass spectrometry, imides, 3,4- and 2,3-pyridinedicarboximides, fragmentation pathways

\section{Introduction}

Mass spectrometry (MS) is a widely employed method for characterization and structural determination of organic compounds. Its advantage over other spectroscopic methods is that it requires a minimal amount of substance. On the other hand, contaminated samples or mixtures of compounds can be analyzed in equipments where mass spectrometry is combined with chromatographic methods without previous purification. From its early days, this method has been effectively employed for the structural characterization of aromatic cyclic imides. In particular, fragmentation of phthalimides under electron impact $(\mathrm{EI})^{1}$ was extensively studied among them. Recently we have focused our attention in analogous imides with pyridine nucleus. Thus, the behavior of a series of $N$-substituted 2,3-pyridinedicarboximides under EI at $70 \mathrm{eV}$ was analyzed. ${ }^{2}$ Ongoing with our research line, we were interested in evaluating the behavior of the isomeric 3,4pyridinedicarboximides. Although they proved to be interesting as synthetic intermediates ${ }^{3}$ and by the biological activity observed for some terms, ${ }^{4} \mathrm{MS}$ of such compounds, has almost not been studied. Bentley and Johnstone described spectra of $N$-methyl and $N$-phenyl-3,4- 
pyridinedicarboximides and concluded that such compounds undergo fragmentation mainly by expulsion of molecules from molecular ion: formimine in $\mathrm{N}$-methyl derivative and phenyl isocyanate in $N$-phenyl derivative. ${ }^{\text {la }}$

We present in this work special features of mass spectra under EI of a series of $N$-functionalized alkyl 3,4-pyridinedicarboximides. We had special interest in the behavior of the corresponding $\omega$ imidoalkanoic acids and their derivatives (esters, amides and related ketone). For a better analysis of their fragmentation, compounds under study were divided into three groups: 3,4pyridinedicarboximidoacetic acid, $\beta$-(3,4-pyridinedicarboximido)propionic acid and $\gamma-(3,4-$ pyridinedicarboximido)butyric acid derivatives (compounds $\mathbf{1 , 2}$ and $\mathbf{3}$ respectively) (Figure 1). In order to observe the influence of pyridine nitrogen position, results were compared in some cases with the corresponding 2,3-pyridinedicarboximide derivatives 4 .

Proposed fragmentation pathways are supported on high resolution mass spectrometry (HRMS) data and MS/MS experiments of selected compounds.

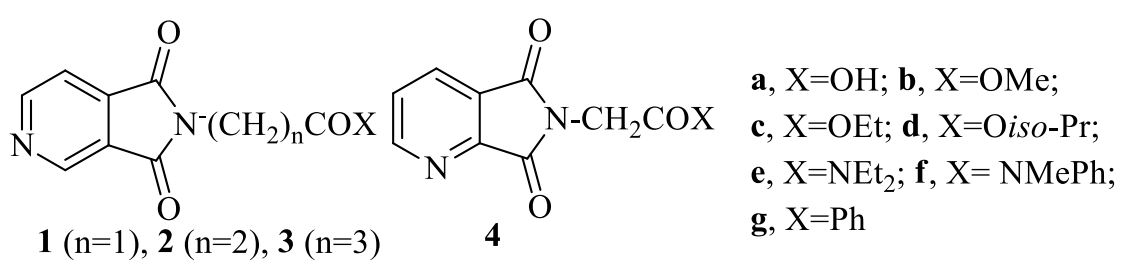

Figure 1. 3,4-Pyridinedicarboximides 1-3 and 2,3-pyridinedicarboximides 4 studied.

\section{Results and Discussion}

\section{3,4-Pyridinedicarboximidoacetic acid (1a)}

Mass spectrum of acid 1a displays $\mathrm{M}^{+\cdot}$ of low abundance (3\%) (Table 1) and presents two characteristic peaks at $\mathrm{m} / \mathrm{z} 161$ and 162 which relative intensities vary according to the electron energy employed. HRMS shows that ion at $m / z 161$ (base ion) corresponds to formula $\mathrm{C}_{8} \mathrm{H}_{5} \mathrm{~N}_{2} \mathrm{O}_{2}$, so stabilized iminium ion $\mathbf{A}$ structure is assigned. Further degradation explains the presence of ions at $\mathrm{m} / \mathrm{z} 134,106,78$ and 51 as the result of successive expulsion of $\mathrm{HCN}, 2 \mathrm{CO}$ and $\mathrm{HCN}$ again (Scheme 1).

HRMS of the $\mathrm{m} / \mathrm{z} 162$ ion shows that it corresponds in composition to $\mathrm{C}_{8} \mathrm{H}_{6} \mathrm{~N}_{2} \mathrm{O}_{2}$ originated from molecular ion decarboxylation. Structure $\mathbf{B}$ arising from a rearrangement which involves carboxyl hydrogen transfer to imide nitrogen with simultaneous cleavage of side chain $\mathrm{C} \alpha-\mathrm{C} \beta$ bond is proposed. Similar rearrangements were observed for 2,3-pyridinedicarboximidoacetic acid $\mathbf{4} \mathbf{a}^{2}$ and other $N$-substituted imides ${ }^{1,5}$ and require the presence of a $\gamma$-hydrogen to imide nitrogen. Other probable structure would be that corresponding to $N$-methyl-3,4-pyridinedicarboximide molecular ion. However, absence of ions at $m / z$ 133, 118 and 105, characteristic of such compound ${ }^{6}$ allows us to discard it. MS/MS experiments show that degradation of $\mathrm{m} / \mathrm{z} 162$ ion involves loss of hydrogen radical leading to iminium ion $\mathbf{A}(\mathrm{m} / \mathrm{z}, 161)$. This pathway $(\mathbf{B} \rightarrow \mathbf{A})$ accounts for differences 
between relative abundances of $\mathrm{m} / \mathrm{z}, 162$ ion in spectra taken at $20 \mathrm{eV}(97 \%)$ and $70 \mathrm{eV}(47 \%){ }^{7}$ However, direct transformation of $\mathrm{M}^{+\cdot}$ by loss of $\mathrm{CO}_{2} \mathrm{H}$ can not be discarded as another source of iminium ions A (Scheme 1).<smiles>O=C(O)CN1C(=O)c2ccncc2C1=O</smiles><smiles>O=C(O)CN1C(=O)c2cccnc2C1=O</smiles>

1a $\left(\mathrm{M}^{+}\right), m / z 206, \mathrm{C}_{9} \mathrm{H}_{6} \mathrm{~N}_{2} \mathrm{O}_{4}$ 4a $\left(\mathrm{M}^{+}\right), m / z 206, \mathrm{C}_{9} \mathrm{H}_{6} \mathrm{~N}_{2} \mathrm{O}_{4}$<smiles>O=C(O)CCCCCCCCCCCCCCO</smiles><smiles>CC12CCC(CC1C(=O)O)C(C(=O)O)C2</smiles><smiles>[3H]C(=O)CC=O</smiles>

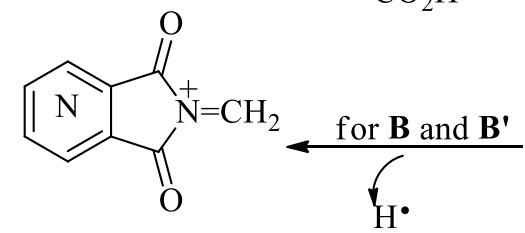<smiles>C[N+]1(C)C(=O)c2ccccc2C1=O</smiles>

A (for 1a) $\mathbf{A}^{\prime}$ (for 4a) $m / z 161, \mathrm{C}_{8} \mathrm{H}_{5} \mathrm{~N}_{2} \mathrm{O}_{4}$

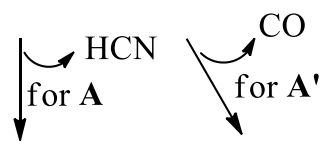

B (for 1a), B' (for 4a) $m / z 162, \mathrm{C}_{8} \mathrm{H}_{6} \mathrm{~N}_{2} \mathrm{O}_{4}$<smiles>O=Cc1ccncc1C(=O)[O-]</smiles><smiles></smiles><smiles>C[NH+]1CC1=O</smiles>

$$
\begin{array}{ccc}
m / z 134 & m / z 133 & m / z 134 \\
\mathrm{C}_{7} \mathrm{H}_{4} \mathrm{NO}_{2} & \mathrm{C}_{7} \mathrm{H}_{5} \mathrm{~N}_{2} \mathrm{O} & \mathrm{C}_{7} \mathrm{H}_{6} \mathrm{~N}_{2} \mathrm{O}
\end{array}
$$
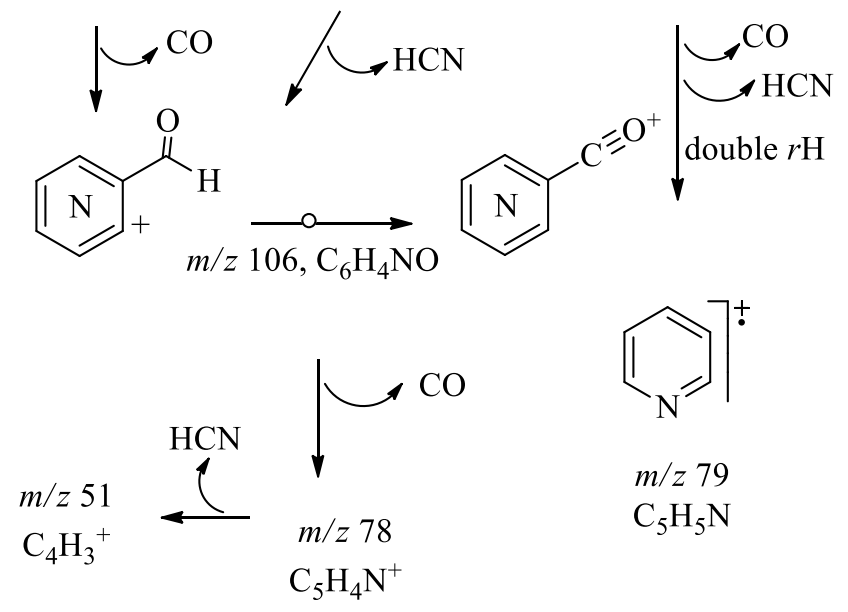

Scheme 1. Fragmentation pathways of 3,4- and 2,3-pyridinedicarboximidoacetic acids 1a and 4a under EI conditions. 
Table 1. Select fragments in the EI mass spectra of 3,4-pyridinedicarboximidoacetic acid 1a and the corresponding esters $\mathbf{1 b}, \mathbf{c}$<smiles>[R]OCN1C(=O)c2ccncc2C1=O</smiles>

\begin{tabular}{|c|c|c|c|}
\hline Ion & $\begin{array}{c}\mathbf{1 a}(\mathrm{R}=\mathrm{H}) \\
m / z(R A \%)^{\mathrm{a}}\end{array}$ & $\begin{array}{l}\mathbf{1 b}(\mathrm{R}=\mathrm{Me}) \\
m / z(R A \%)^{\mathrm{a}}\end{array}$ & $\begin{array}{c}\mathbf{1 c}(\mathrm{R}=\mathrm{Et}) \\
m / z(R A \%)^{\mathrm{a}}\end{array}$ \\
\hline$[\mathrm{M}]^{+}$ & $\begin{array}{c}206 \text { (3). HRMS: } \\
\text { 206.0364. Calcd for } \\
\mathrm{C}_{9} \mathrm{H}_{6} \mathrm{~N}_{2} \mathrm{O}_{4}: 206.0328\end{array}$ & $\begin{array}{c}220 \text { (36). HRMS: } 220.0487 . \\
\text { Calcd for } \mathrm{C}_{10} \mathrm{H}_{8} \mathrm{~N}_{2} \mathrm{O}_{4}: \\
220.0484\end{array}$ & $\begin{array}{c}234 \text { (8). HRMS: } 234.0641 \\
\text { Calcd for } \mathrm{C}_{11} \mathrm{H}_{10} \mathrm{~N}_{2} \mathrm{O}_{4} \\
234.0641\end{array}$ \\
\hline$[\mathrm{M}-\mathrm{RO}]^{+}$ & - & $\begin{array}{c}189 \text { (4). HRMS: } 189.0315 . \\
\text { Calcd for } \mathrm{C}_{9} \mathrm{H}_{5} \mathrm{~N}_{2} \mathrm{O}_{3}: \\
189.0300\end{array}$ & $\begin{array}{c}189 \text { (3). HRMS: } 189.0342 . \\
\text { Calcd for } \mathrm{C}_{9} \mathrm{H}_{5} \mathrm{~N}_{2} \mathrm{O}_{3}: 189.0300\end{array}$ \\
\hline $\begin{array}{c}m / z 162 \\
{[\mathbf{B}]^{+}}\end{array}$ & $\begin{array}{c}\text { (48). }{ }^{\mathrm{b}} \mathrm{HRMS}: \\
\text { 162.0428. Calcd for } \\
\mathrm{C}_{8} \mathrm{H}_{6} \mathrm{~N}_{2} \mathrm{O}_{2}: 162.0429\end{array}$ & - & $\begin{array}{l}\text { (39). }{ }^{\mathrm{b}} \mathrm{HRMS}: 162.0419 . \text { Calcd } \\
\text { for } \mathrm{C}_{8} \mathrm{H}_{6} \mathrm{~N}_{2} \mathrm{O}_{2}: 162.0429\end{array}$ \\
\hline $\begin{array}{c}m / z 161 \\
{[\mathbf{A}]^{+}}\end{array}$ & $\begin{array}{c}\text { (100). HRMS: } \\
\text { 161.0352. Calcd for } \\
\mathrm{C}_{8} \mathrm{H}_{5} \mathrm{~N}_{2} \mathrm{O}_{2}: 161.0351\end{array}$ & $\begin{array}{c}\text { (100). HRMS: } 161.0356 . \\
\text { Calcd for } \mathrm{C}_{8} \mathrm{H}_{5} \mathrm{~N}_{2} \mathrm{O}_{2} \text { : } \\
161.0351\end{array}$ & $\begin{array}{l}\text { (100). HRMS: 161.0349. Calcd } \\
\text { for } \mathrm{C}_{8} \mathrm{H}_{5} \mathrm{~N}_{2} \mathrm{O}_{2}: 161.0351\end{array}$ \\
\hline $\begin{array}{c}m / z 134 \\
{[\mathbf{A}-\mathrm{HCN}]^{+}}\end{array}$ & $\begin{array}{c}\text { (15). HRMS: } 134.0262 . \\
\text { Calcd for } \mathrm{C}_{7} \mathrm{H}_{4} \mathrm{NO}_{2} \text { : } \\
134.0242\end{array}$ & $\begin{array}{c}\text { (10). HRMS: } 134.0260 . \\
\text { Calcd for } \mathrm{C}_{7} \mathrm{H}_{4} \mathrm{NO}_{2} \text { : } \\
134.0242\end{array}$ & $\begin{array}{l}\text { (7). HRMS: } 134.0261 . \text { Calcd } \\
\text { for } \mathrm{C}_{7} \mathrm{H}_{4} \mathrm{NO}_{2}: 134.0242\end{array}$ \\
\hline$m / z 106$ & $\begin{array}{c}\text { (16). HRMS: } 106.0299 . \\
\text { Calcd for } \mathrm{C}_{6} \mathrm{H}_{4} \mathrm{NO} \text { : } \\
106.0293\end{array}$ & $\begin{array}{c}\text { (10). HRMS: } 106.0311 . \\
\text { Calcd for } \mathrm{C}_{6} \mathrm{H}_{4} \mathrm{NO} \text { : } \\
106.0293\end{array}$ & $\begin{array}{l}\text { (8). HRMS: 106.0297. Calcd } \\
\text { for } \mathrm{C}_{6} \mathrm{H}_{4} \mathrm{NO}: 106.0293\end{array}$ \\
\hline$m / z 105$ & & $\begin{array}{c}\text { (18). HRMS: } 105.0248 . \\
\text { Calcd for } \mathrm{C}_{6} \mathrm{H}_{3} \mathrm{NO} \text { : } \\
105.0215\end{array}$ & $\begin{array}{l}\text { (16). HRMS: 105.0228. Calcd } \\
\text { for } \mathrm{C}_{6} \mathrm{H}_{3} \mathrm{NO}: 105.0215\end{array}$ \\
\hline$m / z 78$ & $\begin{array}{c}\text { (57). HRMS: } 78.0334 \text {. } \\
\text { Calcd for } \mathrm{C}_{5} \mathrm{H}_{4} \mathrm{~N} \text { : } \\
78.0344\end{array}$ & $\begin{array}{c}\text { (30). HRMS: } 78.0353 . \\
\text { Calcd for } \mathrm{C}_{5} \mathrm{H}_{4} \mathrm{~N}: 78.0344\end{array}$ & $\begin{array}{l}\text { (26). HRMS: 78.0328. Calcd } \\
\text { for } \mathrm{C}_{5} \mathrm{H}_{4} \mathrm{~N}: 78.0344\end{array}$ \\
\hline$m / z 77$ & & $\begin{array}{c}\text { (16). HRMS: } 77.0278 . \\
\text { Calcd for } \mathrm{C}_{5} \mathrm{H}_{3} \mathrm{NO}: 77.0266\end{array}$ & $\begin{array}{l}\text { (15). HRMS: 77.0277. Calcd } \\
\text { for } \mathrm{C}_{5} \mathrm{H}_{3} \mathrm{NO}: 77.0266\end{array}$ \\
\hline$m / z 51$ & $\begin{array}{l}\text { (77). HRMS: } \\
\text { 51.0243. Calcd for } \\
\mathrm{C}_{4} \mathrm{H}_{3}: 51.0235\end{array}$ & $(17)$ & $\begin{array}{l}\text { (17). HRMS: } 51.0246 . \text { Calcd } \\
\text { for } \mathrm{C}_{4} \mathrm{H}_{3}: 51.0235\end{array}$ \\
\hline$m / z 50$ & & $(39)$ & $(43)$ \\
\hline
\end{tabular}

${ }^{a}$ Relative abundances $(R A)$ indicated between parenthesis correspond to low resolution spectra at 70 $\mathrm{eV}$.

${ }^{\mathrm{b}} R A$ of $\mathbf{B}^{+\cdot}$ corrected from the isotopic contribution of $\mathbf{A}^{+}$. 
In order to observe the influence of pyridine nitrogen position, it is convenient to compare above results with those from isomeric acid $\mathbf{4 a}$ described in our previous paper. ${ }^{2}$ It was observed in this compound that both primary fragmentations leading to the corresponding ions at $m / z 161$ (A') and $162\left(\mathbf{B}^{\prime}\right)$, and $\mathbf{B}^{\prime} \rightarrow \mathbf{A}^{\prime}$ conversion are similar to that of compound 1a (Scheme 1).

However, the presence of pyridine nitrogen adjacent to imide carbonyl favors decarbonylation of such ions. Thus, expulsion of $\mathrm{CO}$ from ions at $\mathrm{m} / \mathrm{z} 161$ (A') and 162 (B'), coming from compound 4a, leads initially to ions at $\mathrm{m} / \mathrm{z} 133$ and 134 respectively. Subsequent degradation of $\mathrm{m} / \mathrm{z}$ 134 ion leads to pyridine odd electron $(\mathrm{m} / \mathrm{z}, 79)$ as the result of $\mathrm{CO}$ and HCN expulsion with a double hydrogen transfer to pyridine nucleus. ${ }^{8}$ On the other hand, decarbonylation is not observed in the fragments $\mathbf{A}$ and $\mathbf{B}$ generated from acid 1a.

\section{Alkyl 3,4- and 2,3-pyridinedicarboximidoacetates (1b,c and 4b-d)}

The most important ions of esters $\mathbf{1 b}, \mathbf{c}$ and $\mathbf{4 b - d}$ are depicted in Tables 1 and 2 respectively. Abundances of $\mathrm{M}^{+\cdot}$ are in general low, and decreasing as the size of alkyl groups increase. Primary fragmentations of both series of compounds are similar and are shown in Scheme 2.

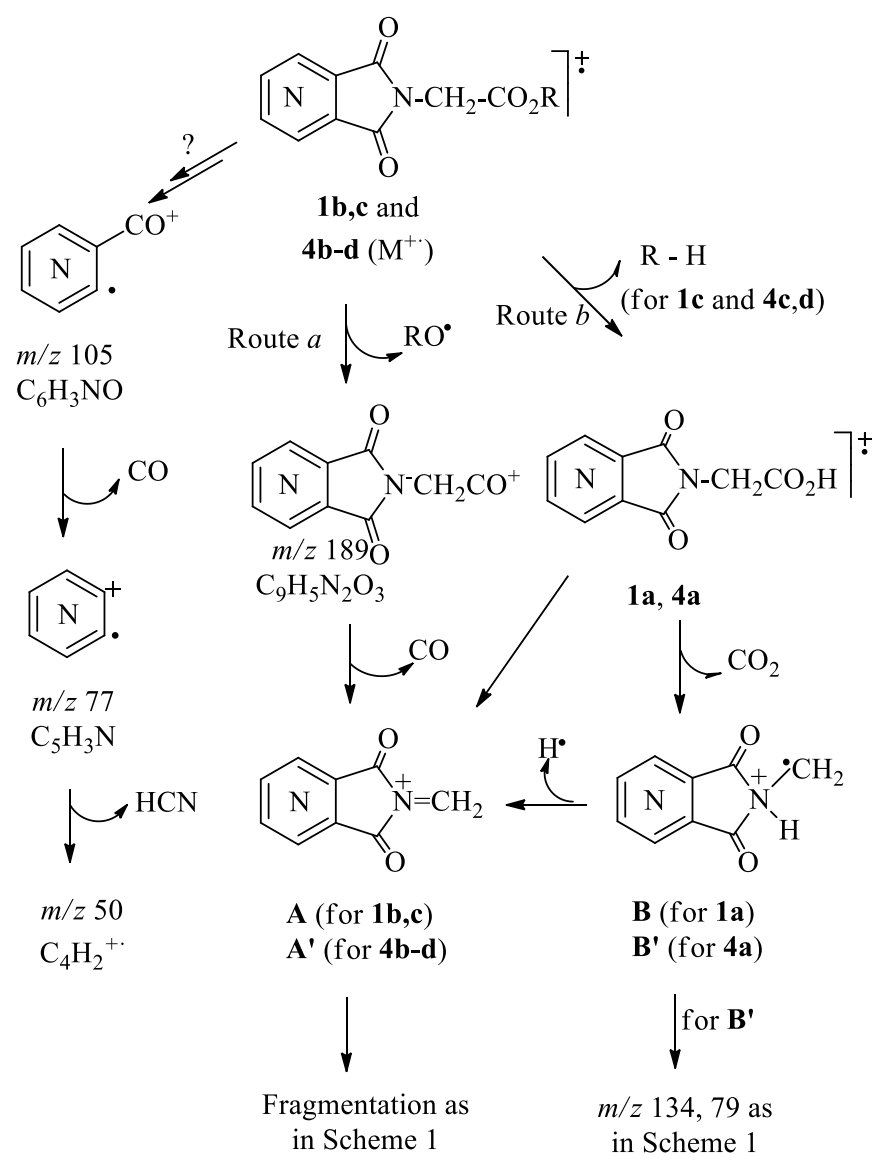

Scheme 2. Fragmentation pathways of 3,4- and 2,3-pyridinedicarboximideacetic acid alkyl esters 1b,c and 4b-d under EI conditions. 
The main fragmentation pathway involves loss of RO by homolytic cleavage originating acylium ion at $m / z 189$, always present although with low intensity, which allows to determine the nature of alkyl group (Route $\boldsymbol{a}$ ). Subsequent expulsion of CO generates the corresponding iminium ions (A and A', base ions) and ions derived from them.

Table 2. Select fragments in the EI mass spectra of 2,3-pyridinedicarboximidoacetic acid alkyl esters $\mathbf{4 b - d}$

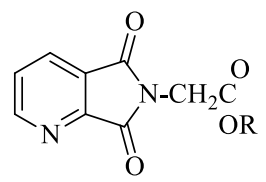

\begin{tabular}{|c|c|c|c|}
\hline Ion & $\begin{array}{l}\text { 4b }(\mathrm{R}=\mathrm{Me}) \\
m / z(R A \%)^{\mathrm{a}}\end{array}$ & $\begin{array}{l}\mathbf{4 c}(\mathrm{R}=\mathrm{Et}) \\
m / z(R A \%)^{\mathrm{a}}\end{array}$ & $\begin{array}{c}4 \mathbf{d}(\mathrm{R}=i s o-\mathrm{Pr}) \\
m / z(R A \%)^{\mathrm{a}}\end{array}$ \\
\hline$[\mathrm{M}]^{+\cdot}$ & $220(23)$ & $234(3)$ & $248(<1)^{\mathrm{c}}$ \\
\hline$[\mathrm{M}-\mathrm{RO}]^{+}$ & $189(2)$ & $189(1)$ & $\begin{array}{l}189 \text { (8). HRMS: 189.0306. Calcd for } \\
\mathrm{C}_{9} \mathrm{H}_{5} \mathrm{~N}_{2} \mathrm{O}_{3}: 189.0300\end{array}$ \\
\hline$\left[\mathrm{M}-\mathrm{CO}_{2}\right]^{+\cdot}$ & $176(2)$ & $190(2)$ & $\begin{array}{l}204 \text { (1). HRMS: 204.0879. Calcd for } \\
\mathrm{C}_{11} \mathrm{H}_{12} \mathrm{~N}_{2} \mathrm{O}_{2}: 204.0899\end{array}$ \\
\hline $\begin{array}{c}m / z, 162 \\
{\left[\mathbf{B}^{\prime}\right]^{+\cdot}}\end{array}$ & - & $(25)^{\mathrm{b}}$ & $\begin{array}{l}\text { (52). }{ }^{\mathrm{b}} \mathrm{HRMS:} \text { 162.0430. Calcd for } \\
\mathrm{C}_{8} \mathrm{H}_{6} \mathrm{~N}_{2} \mathrm{O}_{2}: 162.0429\end{array}$ \\
\hline $\begin{array}{c}m / z, 161 \\
{\left[\mathbf{A}^{\prime}\right]^{+}}\end{array}$ & $(100)$ & $(100)$ & $\begin{array}{l}\text { (100). HRMS: 161.0363. Calcd for } \\
\mathrm{C}_{8} \mathrm{H}_{5} \mathrm{~N}_{2} \mathrm{O}_{2}: 161.0351\end{array}$ \\
\hline $\begin{array}{c}m / z 134 \\
{\left[\mathbf{B}^{\prime}-\mathrm{CO}\right]^{+\cdot}}\end{array}$ & - & (4) & $\begin{array}{c}\text { (13). HRMS 134.0501. Calcd for } \mathrm{C}_{7} \mathrm{H}_{6} \mathrm{~N}_{2} \mathrm{O} \text { : } \\
134.0480\end{array}$ \\
\hline $\begin{array}{c}m / z 133 \\
{\left[\mathbf{A}^{\prime}-\mathrm{CO}\right]^{+}}\end{array}$ & (7) & $(5)$ & $\begin{array}{c}\text { (8). HRMS: } 133.0389 . \text { Calcd for } \mathrm{C}_{7} \mathrm{H}_{5} \mathrm{~N}_{2} \mathrm{O} \text { : } \\
133.0402\end{array}$ \\
\hline$m / z 106$ & (37) & (28) & $\begin{array}{c}\text { (34). HRMS: } 106.0307 . \text { Calcd for } \mathrm{C}_{6} \mathrm{H}_{4} \mathrm{NO} \text { : } \\
106.0293\end{array}$ \\
\hline$m / z 105$ & (9) & (15) & $\begin{array}{c}\text { (13). HRMS: } 105.0243 . \text { Calcd for } \mathrm{C}_{6} \mathrm{H}_{3} \mathrm{NO} \text { : } \\
105.0215\end{array}$ \\
\hline$m / z 79$ & (1) & (9) & $\begin{array}{c}\text { (21). HRMS: } 79.0430 . \text { Calcd for } \mathrm{C}_{5} \mathrm{H}_{5} \mathrm{~N} \text { : } \\
79.0422\end{array}$ \\
\hline$m / z 78$ & (13) & (23) & $\begin{array}{c}\text { (31). HRMS: } 78.0338 . \text { Calcd for } \mathrm{C}_{5} \mathrm{H}_{4} \mathrm{~N} \text { : } \\
78.0344\end{array}$ \\
\hline$m / z 77$ & (3) & (19) & $\begin{array}{c}\text { (23). HRMS: } 77.0276 . \text { Calcd for } \mathrm{C}_{5} \mathrm{H}_{3} \mathrm{~N} \text { : } \\
77.0266\end{array}$ \\
\hline$m / z, 51$ & (2) & (7) & (24) \\
\hline$m / z 50$ & (15) & $(7)$ & $(23)$ \\
\hline
\end{tabular}

${ }^{a}$ Relative abundances $(R A)$ indicated between parenthesis correspond to low resolution spectra at 70 $\mathrm{eV} .{ }^{\mathrm{b}} R A$ of $\mathbf{B}^{+\cdot}$ corrected from the isotopic contribution of $\mathbf{A}^{+} .{ }^{\mathrm{c}}$ This ion is not detected in the HRMS. 
Ethyl 1c and 4c and isopropyl 4d ester spectra show $\mathrm{m} / \mathrm{z} 162$ ions (25-52\%) assigned to structures $\mathbf{B}$ and $\mathbf{B}$ '. The presence of such ions is probably the result of a McLafferty rearrangement of esters having $\gamma$-hydrogen to carbonyl leading to the 1a and 4a molecular ions $(\mathrm{m} / \mathrm{z} 206)$ (Route b). Although spectra of those compounds at $70 \mathrm{eV}$ do not show these ions, spectrum of $\mathbf{1 c}$ recorded at $20 \mathrm{eV}$ shows a low intensity peak at $\mathrm{m} / z 206(5 \%)$, endorsing route $\boldsymbol{b} .{ }^{9}$

On the other hand, experimental results performed with isopropyl ester $4 \mathbf{d d}$, having two methyls capable to transfer their hydrogens in a McLafferty rearrangement generating 4a molecular ion, also support the route $\boldsymbol{b}$. Thus, when $\mathbf{4 d}$ spectra were recorded using different electron been energy, abundances of ions at $\mathrm{m} / \mathrm{z}, 162,134$ and 79 (in relation to that of $\mathrm{m} / \mathrm{z}, 161$ ion) increase as electron energy decrease following the behaviour observed for acid $\mathbf{4 a} .{ }^{10}$

All esters also present ions at $\mathrm{m} / z 105\left(\mathrm{C}_{6} \mathrm{H}_{3} \mathrm{NO}\right), 77\left(\mathrm{C}_{5} \mathrm{H}_{3} \mathrm{~N}\right)$ and $50\left(\mathrm{C}_{4} \mathrm{H}_{2}\right)$, common in this type of pyridine derivatives, which probably result from other fragmentation pathways of $\mathrm{M}^{+\cdot}$ (Scheme 2).

\section{3,4-Pyridinedicarboximidoacetamides (1e,f)}

Decomposition of amides 1e,f reflects the strong tendency of carboxamide nitrogen to undergo reactions originating ions with charge retention (Table 3). Three primary fragmentation pathways are observed in the spectra, depicted in Scheme 3.

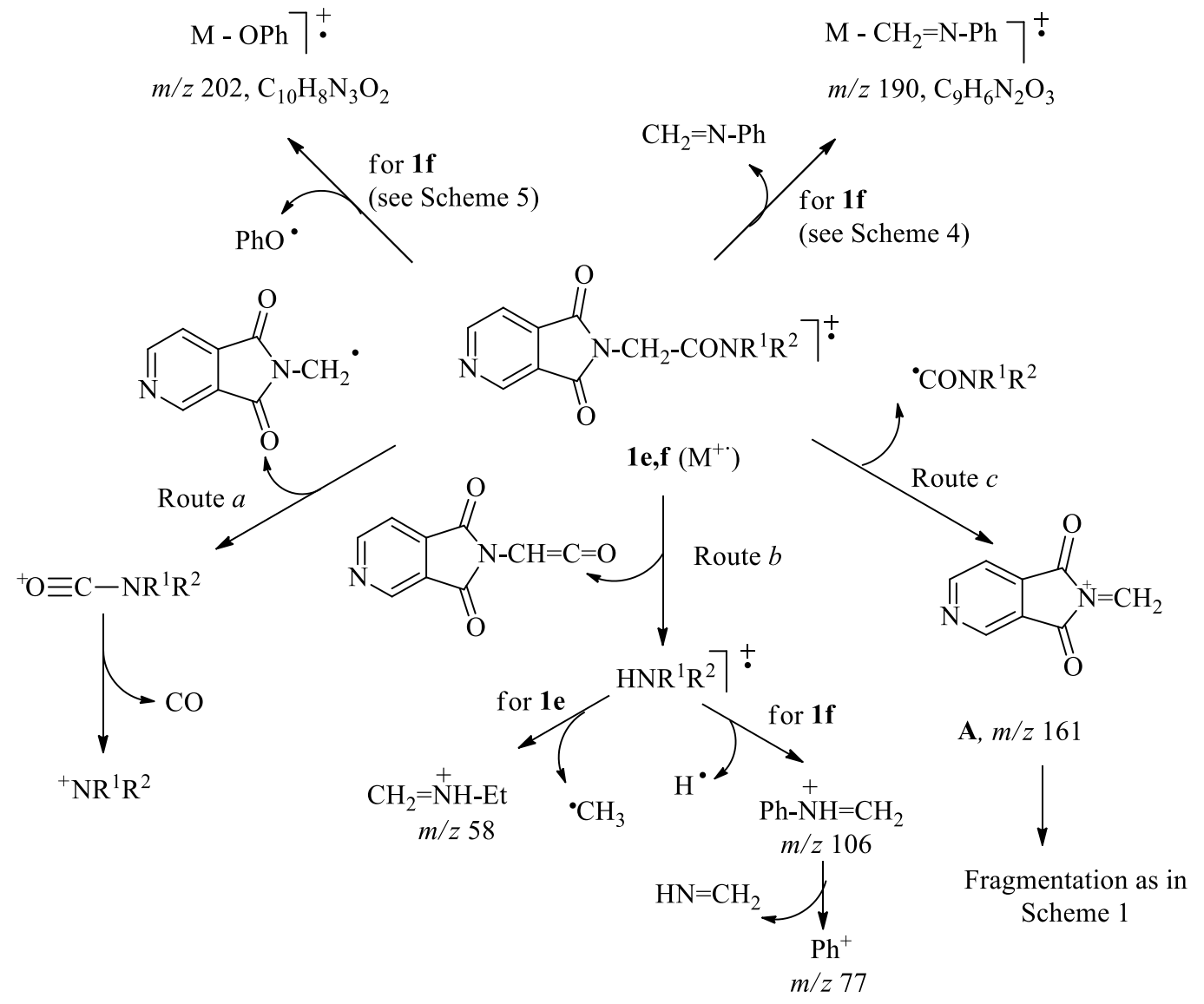

Scheme 3. Fragmentation pathways of 3,4-pyridinedicarboximidoacetamides 1e,f under EI conditions. 
Table 3. Select fragments in the EI mass spectra of 3,4-pyridinedicarboximidoacetamides 1e,f<smiles>[R12]NCN1C(=O)c2ccncc2C1=O</smiles>

\begin{tabular}{|c|c|c|}
\hline Ion & $\begin{array}{c}\text { 1e }\left(\mathrm{R}^{1}=\mathrm{R}^{2}=\mathrm{Et}\right) \\
m / z(R A \%)^{\mathrm{b}}\end{array}$ & $\begin{array}{c}\text { 1f }\left(\mathrm{R}^{1}=\mathrm{Me}, \mathrm{R}^{2}=\mathrm{Ph}\right) \\
m / z(R A \%)^{\mathrm{b}}\end{array}$ \\
\hline$[\mathrm{M}]^{+\cdot}$ & $261(16)$ & $\begin{array}{c}295 \text { (63). HRMS: } 295.0956 . \text { Calcd for } \mathrm{C}_{16} \mathrm{H}_{13} \mathrm{~N}_{3} \mathrm{O}_{3} \text { : } \\
295.0957\end{array}$ \\
\hline$\left[\mathrm{CONR}^{1} \mathrm{R}^{2}\right]^{+}$ & $100(86)$ & 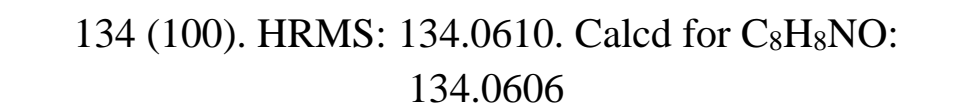 \\
\hline$\left[\mathrm{NR}^{1} \mathrm{R}^{2}\right]^{+}$ & $72(100)$ & 106 (55). HRMS $106.0655^{\mathrm{c}}$. Calcd for $\mathrm{C}_{7} \mathrm{H}_{8} \mathrm{~N} 106.0657$ \\
\hline $\begin{array}{c}{\left[\mathrm{HNR}^{1} \mathrm{R}^{2}\right]^{+\cdot}} \\
m / z 189\end{array}$ & (1) & $\begin{array}{c}107(57)^{\mathrm{d}} . \text { HRMS: } 107.0729 . \text { Calcd for } \mathrm{C}_{7} \mathrm{H}_{9} \mathrm{~N}: 107.0735 \\
(1)^{\mathrm{e}}\end{array}$ \\
\hline$\left[\mathrm{M}-\mathrm{NR}^{1} \mathrm{R}^{2}\right]^{+}$ & & \\
\hline $\begin{array}{l}m / z 161 \\
{[\mathbf{A}]^{+}}\end{array}$ & $(29)$ & (60). HRMS: 161.0360. Calcd for $\mathrm{C}_{8} \mathrm{H}_{5} \mathrm{~N}_{2} \mathrm{O}_{2}: 161.0351$ \\
\hline $\begin{array}{c}m / z 134 \\
{[\mathbf{A}-\mathrm{HCN}]^{+}}\end{array}$ & $(2)$ & $\mathrm{f}$ \\
\hline$m / z 106$ & $(3)$ & c \\
\hline$m / z 78$ & $(15)$ & (33). HRMS: 78.0365. Calcd for $\mathrm{C}_{5} \mathrm{H}_{4} \mathrm{~N}: 78.0344$ \\
\hline$m / z 51$ & $(12)$ & (28). HRMS: 51.0242. Calcd for $\mathrm{C}_{4} \mathrm{H}_{3}: 51.0235$ \\
\hline$m / z 50$ & $(26)$ & $(29)$ \\
\hline Others $^{\mathrm{a}}$ & $\begin{array}{c}58(19) \\
{\left[\mathrm{HNEt}_{2}-\mathrm{Me}\right]^{+}}\end{array}$ & $\begin{array}{l}202 \text { (3). HRMS: 202.0602. Calcd for } \mathrm{C}_{10} \mathrm{H}_{8} \mathrm{~N}_{3} \mathrm{O}_{2} \text { : } \\
\text { 202.0617, [M-PhO] }]^{+} \\
190 \text { (2). HRMS: } 190.0361 . \text { Calcd for } \mathrm{C}_{9} \mathrm{H}_{6} \mathrm{~N}_{2} \mathrm{O}_{3} \\
\text { 190.0378, [M-CH}=\mathrm{NPh}]^{+} \\
77 \text { (64). HRMS: 77.0391. Calcd for } \mathrm{C}_{6} \mathrm{H}_{5}: 77.0391\end{array}$ \\
\hline
\end{tabular}

${ }^{\mathrm{a}}$ Characteristic peaks and/or with relative abundance higher than $15 \%$ are depicted.

${ }^{\mathrm{b}}$ Relative abundances $(R A)$ indicated between parenthesis correspond to low resolution spectra at 70 $\mathrm{eV}$.

${ }^{c}$ The most abundant ion at $\mathrm{m} / z, 106$ corresponds to formula $\mathrm{C}_{7} \mathrm{H}_{8} \mathrm{~N}$ and results from the contributions of two isomeric ions (see text).

${ }^{\mathrm{d}} R A$ of $\left[\mathrm{HNR}{ }^{1} \mathrm{R}^{2}\right]^{+\cdot}$ corrected from the isotopic contribution of $\left[\mathrm{NR}^{1} \mathrm{R}^{2}\right]^{+}$.

'This ion is not detected in the HRMS.

${ }^{\mathrm{f}}$ The most abundant ion at $\mathrm{m} / \mathrm{z} 134$ corresponds to [CONMePh$]^{+}$.

The most important pathway involves an $\alpha$-cleavage leading to carboxamide ion $\left[\mathrm{CONR}^{1} \mathrm{R}^{2}\right]^{+}$, base ion for $\mathbf{1 f}(\mathrm{m} / \mathrm{z}$ 134) (Route $\boldsymbol{a})$. Fragmentation continues with the loss of $\mathrm{CO}$ originating $\left.\left[N R^{1} \mathbf{R}^{2}\right]^{+}\right)$, base ion for $1 \mathbf{e}(\mathrm{m} / \mathrm{z}, 72)$. 
Route $\boldsymbol{b}$ involves CO-N cleavage with hydrogen transfer to nitrogen. Such cleavage is typical of acetamides $^{11}$ leading to odd electron ions $\left[\operatorname{HNR}^{1} \mathrm{R}^{2}\right]^{+\cdot}(\mathrm{m} / \mathrm{z} 107,62 \%$ for compound 1f). It is interpreted as the result of a methylene hydrogen transfer to carboxamide nitrogen, subsequent homolytic cleavage with charge retention on nitrogen and expulsion of a substituted ketene. On the other hand, MS/MS experiments demonstrate that the strong peak at $\mathrm{m} / \mathrm{z} 106(64 \%)$ results from the contribution of two isomeric ions of formula $\mathrm{C}_{7} \mathrm{H}_{8} \mathrm{~N}$ : the expected $[\mathrm{NMePh}]^{+}$arising from carboxamide cation $[\mathrm{CONMePh}]^{+}(\mathrm{m} / \mathrm{z}, 134)$ decarbonylation and the phenylmethaniminium ion $\left[\mathrm{CH}_{2}=\mathrm{NHPh}\right]^{+}$resulting from $[\mathrm{HNMePh}]^{+\cdot}(\mathrm{m} / \mathrm{z}, 107) \alpha$-cleavage. ${ }^{12}$

Although compound 1e spectrum lacks of $\left[\mathrm{NHEt}_{2}\right]^{+\cdot}$ radical ion $(\mathrm{m} / \mathrm{z} 73), \mathrm{m} / \mathrm{z} 58$ ion $\left[\mathrm{HNEt}_{2}\right.$ $\mathrm{Me}]^{+}$arising from $\alpha$-cleavage, is observed; therefore Route $\boldsymbol{b}$ cannot be discarded for this compound.

Route $\boldsymbol{c}$ leads to the stabilized iminium ion $\mathbf{A}(\mathrm{m} / \mathrm{z}, 161)$, either through an intermediary acyl ion $\left[\mathrm{M}-\mathrm{NR}^{1} \mathrm{R}^{2}\right]^{+}(\mathrm{m} / \mathrm{z}, 189)$ which is detected with very low abundance, or by direct $\alpha$-cleavage of the molecular ion.

1f Spectrum also exhibits ions which are characteristic of $N$-methylanilides at $\mathrm{m} / z, 190$ and 202, of low intensity but easily recognized in the high mass zone. $M / z 190$ ion results from expulsion of $\mathrm{N}$-phenylmethanimine as a consequence of a carboxamide five center rearrangement ${ }^{13}$ which requires the presence of a $\beta$-hydrogen to carbonyl (Scheme 4). Ion at $m / z 202$ has its origin in the loss of $\mathrm{PhO}$ from the molecular ion. It is an example of amide rearrangement rationalized by Bentley and Johnstone ${ }^{14}$ occurring through a tetra-membered transition state in which $\mathrm{p} \pi-$ centres participation plays a fundamental role (Scheme 5).

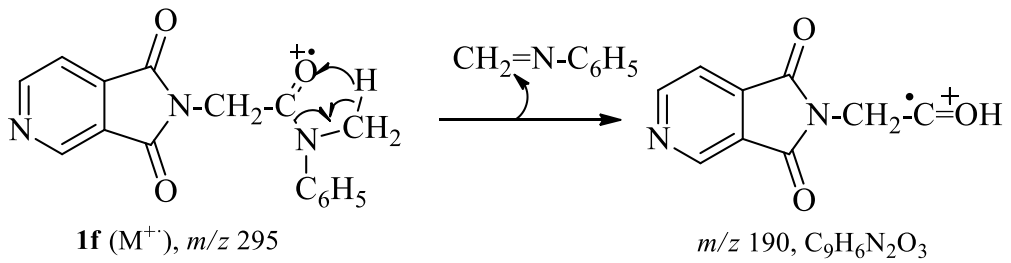

Scheme 4. Fragmentation of compound 1f with loss of $N$-phenylmethanimine.

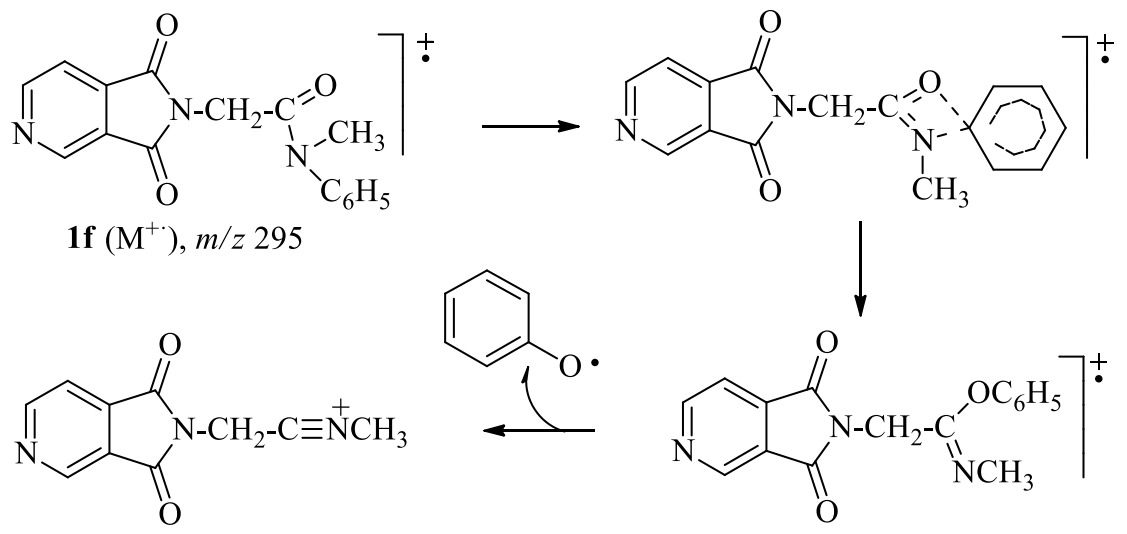

$m / z 202, \mathrm{C}_{10} \mathrm{H}_{8} \mathrm{~N}_{3} \mathrm{O}_{2}$

Scheme 5. Fragmentation of compound $\mathbf{1 f}$ with loss of phenoxide radical. 


\section{$\boldsymbol{\beta}$-(3,4-Pyridinedicarboximido)propionic acid and esters (2a-c)}

Spectra of $\beta$-(3,4-pyridinedicarboximido)propionic acid $\mathbf{2 a}$ and its esters $\mathbf{2 b}$ and $\mathbf{2 c}$ show similar features, with low $\mathrm{M}^{+\cdot}$ abundances (Table 4). The main fragmentation pathway leads to the base ion at $m / z$ 174, of formula $\mathrm{C}_{9} \mathrm{H}_{6} \mathrm{~N}_{2} \mathrm{O}_{2}$ compatible with that of the $N$-vinyl-3,4-pyridinedicarboximide (Scheme 6, Route $\boldsymbol{a}$ ). It results from the loss of $\mathrm{ROH}$ as a consequence of hydrogen rearrangement from the alkyl side chain to a saturated oxigen with adjacent cleavage, followed by the expulsion of CO. MS/MS experiments show that $m / z, 174$ ion degrades through two main routes: subsequent loss of two molecules of $\mathrm{CO}$ accounting for ions at $\mathrm{m} / \mathrm{z} 146$ and 118, and expulsion of vinyl isocyanate originating ion at $\mathrm{m} / \mathrm{z} 105$ and those derived from it $(\mathrm{m} / \mathrm{z} 77$ y 50$)$.

Route $\boldsymbol{b}$ begins by the loss of RO' ( $\alpha$-cleavage) leading to acylium ion at $m / z 203$, for which two fragmentation pathways are proposed (Scheme 6). In the first one, ketene is eliminated leading to a prominent iminiun ion A $(\mathrm{m} / \mathrm{z}, 161)(79-83 \%)$ and ions derived from them (Scheme 1). In the second one, two molecules of $\mathrm{CO}$ are subsequently lost, thus justifying the presence of ions at $\mathrm{m} / \mathrm{z} 175$ and 147.

Formation of $\mathrm{m} / \mathrm{z} 148$ ion, for which structure $\mathbf{C}$ is proposed, is probably due to a McLafferty rearrangement (Route $c$ ) as the result of a hydrogen transfer from the alkyl side chain to the imide carbonyl group with charge retention on the imide moiety. Thus, the required presence of hydrogen on a $\beta$-carbon to imide nitrogen is responsible for the appearance of such ions in this series and not in compounds 1. Fragmentation follows with loss of $\mathrm{HO}$ affording $\mathrm{m} / \mathrm{z} 131$ ions. ${ }^{15}$ Further loss of $\mathrm{CN}$, CO and HCN leads to ions at $m / z$ 105, 103, 77 and 50.

\section{$\gamma$-(3,4-Pyridinedicarboximido)butyric acid ethyl ester (3c)}

As in the preceding series, the main fragmentation pathways begins with the loss of ROH (Route $\boldsymbol{a}$ ) and RO (Route $\boldsymbol{b}$ ), thus originating abundant ions at $\mathrm{m} / \mathrm{z} 216$ and 217 respectively. Further side chain degradation leads to characteristic ions at $m / z 189,188,175,174$ and 161 (A, base ion) as it is shown in Scheme 7.

Although less abundant, spectrum also displays characteristic peaks resulting from hydrogen transfer from trimethylene side chain to imide nucleus: ion $\mathbf{C}$ at $\mathrm{m} / z \quad 148$ resulting from a McLafferty rearrangement (Route $\boldsymbol{c}$ ) as in the previous series, and the protonated imide $\mathbf{D}$ at $\mathrm{m} / \mathrm{z}$ 149 (Route $\boldsymbol{d}$ ). Such ion can be proposed to originate through a double hydrogen transfer, from $\beta$ and $\gamma$-carbon atoms of the alkyl chain and $\mathrm{C}-\mathrm{N}$ bond cleavage.

\section{$\mathrm{N}$-Benzoylmethyl-3,4- and 2,3-pyridinedicarboximides (1g and 4g)}

Ketone $\mathbf{1 g}$ and $\mathbf{4 g}$ fragmentations (See Experimental Section) are as expected according to their phenyl ketone character, leading to base ions at $\mathrm{m} / z 105$ corresponding to $\mathrm{C}_{6} \mathrm{H}_{5} \mathrm{CO}^{+}$. Instead, the $\alpha$ cleavage leading to iminium ions $\mathbf{A}, \mathbf{A}^{\prime}$, is in both cases of low importance. The only observable difference between both compounds is the presence in $\mathbf{4 a}$ spectrum of an ion at $\mathrm{m} / \mathrm{z}$ 238, of low abundance but easily recognized, corresponding to $\mathrm{M}^{+\cdot}$ decarbonylation. This fact is again related to the presence of pyridine nitrogen adjacent to imide carbonyl. The effect is in agreement with other substituted pyridine compounds in which differences are observed with substituents in the $\alpha$ - and $\beta$ positions. 
Table 4. Select fragments in the EI mass spectra of $\beta$-(3,4-pyridinedicarboximido)propionic acid 2a and the corresponding esters $\mathbf{2 b , c}$<smiles>[R]OCCN1C(=O)c2ccncc2C1=O</smiles>

\begin{tabular}{|c|c|c|c|}
\hline Ion & $\begin{array}{c}\mathbf{2 a}(\mathrm{R}=\mathrm{H}) \\
m / z(R A \%)^{\mathrm{a}}\end{array}$ & $\begin{array}{l}\mathbf{2 b}(\mathrm{R}=\mathrm{Me}) \\
m / z(R A \%)^{\mathrm{a}}\end{array}$ & $\begin{array}{l}\text { 2c }(\mathrm{R}=\mathrm{Et}) \\
m / z(R A \%)^{\mathrm{a}}\end{array}$ \\
\hline$[\mathrm{M}]^{+\cdot}$ & $\begin{array}{c}220 \text { (4). HRMS: } 220.0536 . \text { Calcd for } \mathrm{C}_{10} \mathrm{H}_{8} \mathrm{~N}_{2} \mathrm{O}_{4} \text { : } \\
220.0484\end{array}$ & $234(19)$ & $248(5)$ \\
\hline $\begin{array}{c}m / z 203 \\
{[\mathrm{M}-\mathrm{RO}]^{+}}\end{array}$ & $\begin{array}{l}\text { (5). HRMS: } 203.0456 . \text { Calcd for } \mathrm{C}_{10} \mathrm{H}_{7} \mathrm{~N}_{2} \mathrm{O}_{3} \text { : } \\
\text { 203.0457 }\end{array}$ & $(32)$ & $(20)$ \\
\hline $\begin{array}{c}m / z 202 \\
{[\mathrm{M}-\mathrm{ROH}]^{+\cdot}}\end{array}$ & $\begin{array}{c}\text { (12). HRMS: 202.0391. Calcd for } \mathrm{C}_{10} \mathrm{H}_{6} \mathrm{~N}_{2} \mathrm{O}_{3} \text { : } \\
\text { 202.0378 }\end{array}$ & $(50)$ & $(18)$ \\
\hline$m / z 175$ & $\begin{array}{c}\text { (29). HRMS: } 175.0489 . \text { Calcd for } \mathrm{C}_{9} \mathrm{H}_{7} \mathrm{~N}_{2} \mathrm{O}_{2} \text { : } \\
175.0508\end{array}$ & $(36)$ & $(16)$ \\
\hline$m / z 174$ & $\begin{array}{l}\text { (100). HRMS: 174.0438. Calcd for } \\
\mathrm{C}_{9} \mathrm{H}_{6} \mathrm{~N}_{2} \mathrm{O}_{2}: 174.0429\end{array}$ & $(100)$ & $(100)$ \\
\hline $\begin{array}{c}m / z 161 \\
{[\mathbf{A}]^{+}}\end{array}$ & $\begin{array}{c}\text { (79). HRMS: } 161.0359 . \text { Calcd for } \mathrm{C}_{8} \mathrm{H}_{5} \mathrm{~N}_{2} \mathrm{O}_{2} \text { : } \\
161.0351\end{array}$ & $(83)$ & $(79)$ \\
\hline $\begin{array}{c}m / z 148 \\
{[\mathbf{C}]^{+\cdot}}\end{array}$ & $\begin{array}{c}\text { (15). HRMS 148.0290. Calcd for } \mathrm{C}_{7} \mathrm{H}_{4} \mathrm{~N}_{2} \mathrm{O}_{2} \text { : } \\
148.0273\end{array}$ & $(16)$ & $(8)$ \\
\hline$m / z 147$ & $\begin{array}{c}\text { (31). HRMS: } 147.0534 . \text { Calcd for } \mathrm{C}_{8} \mathrm{H}_{7} \mathrm{~N}_{2} \mathrm{O}: \\
147.0558\end{array}$ & $(28)$ & (9) \\
\hline$m / z 146$ & $\begin{array}{c}\text { (36). HRMS: } 146.0493 . \text { Calcd for } \mathrm{C}_{8} \mathrm{H}_{6} \mathrm{~N}_{2} \mathrm{O} \text { : } \\
146.0480\end{array}$ & $(36)$ & $(10)$ \\
\hline $\begin{array}{c}m / z 134 \\
{[\mathbf{A}-\mathrm{HCN}]^{+}}\end{array}$ & $\begin{array}{c}\text { (21). HRMS: } 134.0262 . \text { Calcd for } \mathrm{C}_{7} \mathrm{H}_{4} \mathrm{NO}_{2} \text { : } \\
134.0242\end{array}$ & $(18)$ & $(5)$ \\
\hline$m / z 131$ & $\begin{array}{c}\text { (26). HRMS: } 131.0270 . \text { Calcd for } \mathrm{C}_{7} \mathrm{H}_{3} \mathrm{~N}_{2} \mathrm{O}: \\
131.0246\end{array}$ & $(28)$ & $(12)$ \\
\hline$m / z 118$ & (8). HRMS: 118.0549. Calcd for $\mathrm{C}_{7} \mathrm{H}_{6} \mathrm{~N}_{2}: 118.0531$ & $(7)$ & $(2)$ \\
\hline$m / z 106$ & $\begin{array}{c}\text { (25). HRMS: 106.0299. Calcd for } \\
\mathrm{C}_{6} \mathrm{H}_{4} \mathrm{NO}: 106.0293\end{array}$ & $(20)$ & $(10)$ \\
\hline$m / z 105$ & $\begin{array}{c}\text { (38). HRMS: } 105.0226 . \text { Calcd for } \mathrm{C}_{6} \mathrm{H}_{3} \mathrm{NO} \text { : } \\
105.0215\end{array}$ & $(32)$ & $(17)$ \\
\hline$m / z, 103$ & (13). HRMS: 103.0317. Calcd for $\mathrm{C}_{6} \mathrm{H}_{3} \mathrm{~N}_{2}: 103.0297$ & $(10)$ & $(4)$ \\
\hline$m / z 78$ & (67). HRMS: 78.0291. Calcd for $\mathrm{C}_{5} \mathrm{H}_{4} \mathrm{~N}: 78.0344$ & $(53)$ & $(19)$ \\
\hline$m / z 77$ & (60). HRMS: 77.0261. Calcd for $\mathrm{C}_{5} \mathrm{H}_{3} \mathrm{~N}: 77.0265$ & $(44)$ & $(15)$ \\
\hline
\end{tabular}

${ }^{a}$ Relative abundances $(R A)$ indicated between parenthesis correspond to low resolution spectra at 70 $\mathrm{eV}$. 
<smiles>O=C1c2ccncc2C(=O)N1CCO</smiles>

$m / z 175, \mathrm{C}_{9} \mathrm{H}_{7} \mathrm{~N}_{2} \mathrm{O}_{2}$<smiles></smiles><smiles>C=C1c2cnccc2C(=O)N1CCC(=[O+])C1CCCCCCCC1</smiles>

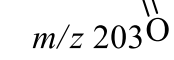
$\mathrm{C}_{10} \mathrm{H}_{7} \mathrm{~N}_{2} \mathrm{O}_{3}$

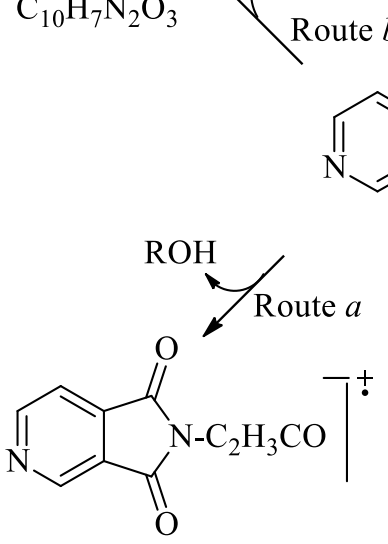

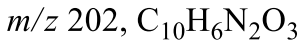<smiles>CCN1C(=O)c2ccncc2C1=O</smiles>

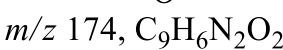

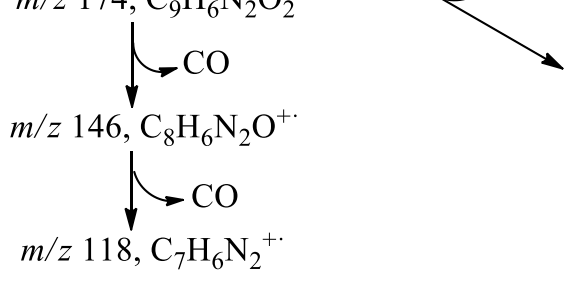

Fragmentation as in Scheme 1

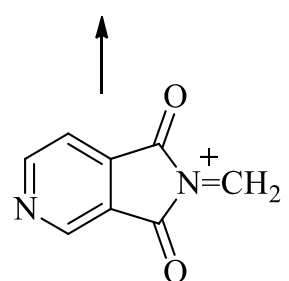

$$
\text { A, } m / z 161
$$

$\mathrm{C}_{8} \mathrm{H}_{5} \mathrm{~N}_{2} \mathrm{O}_{2}$ 


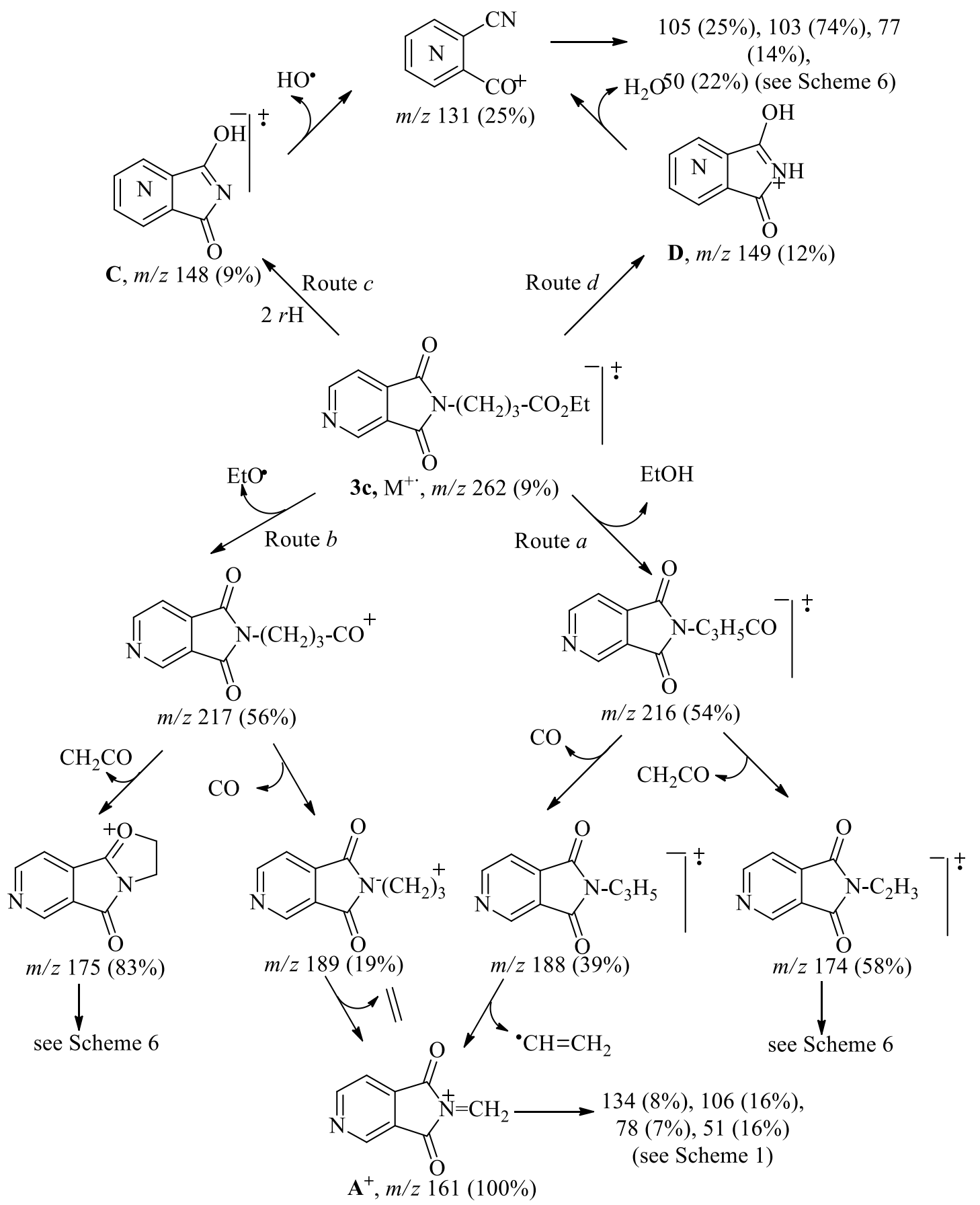

Scheme 7. Fragmentation pathways of $\gamma$-3,4-pyridinedicarboximidobutyric acid ethyl ester 3c under EI conditions.

\section{Conclusions}

The fragmentation of a series of $\omega$-(3,4-pyridinedicarboximido)alkanoic acids and their derivatives 1-3 under EI show differences depending on the length and the function of the imide $N$-substituent. 
Generally, main fragmentations lead to total or partial loss the side chain with charge retention on the imide moiety. Instead, decomposition of the 3,4-pyridinedicarboximidoacetamides reflects the strong tendency of carboxamide nitrogen to undergo reactions originating ions with charge retention: $\left[\mathrm{CONR}{ }^{1} \mathrm{R}^{2}\right]^{+},\left[\mathrm{NR}^{1} \mathrm{R}^{2}\right]^{+}$and $\left[\mathrm{HNR}{ }^{1} \mathrm{R}^{2}\right]^{+}$.

The difference amongst 3,4-pyridinedicarboximides 1-3 to the corresponding 2,3pyridinedicarboximides $\mathbf{4}$ is observed in the fragmentations which produce the cleavage of the imide nucleus.

\section{Experimental Section}

General. Mass spectra were obtained operating under electron impact at $70 \mathrm{eV}$ unless otherwise indicated. Low resolution mass spectra at were recorded with a GC-MS Shimadzu QP-1000 spectrometer._High resolution mass spectra, were acquired with a model GCT (Waters, Milford, $M A, U S A)$, operating at a 8000 resolving power (50\% valley definition) using heptacose $(\mathrm{m} / z$ 219) as the reference compound. Samples were dissolved in chloroform or methanol and introduced into the spectrometer through a gas chromatograph Agilent, model $6890 \mathrm{~N}$ (injector temperature: $300{ }^{\circ} \mathrm{C}$, initial temperature: $100{ }^{\circ} \mathrm{C}$, temperature "ramp": $20^{\circ} \mathrm{C} / \mathrm{min}$, final temperature: $300{ }^{\circ} \mathrm{C}$ ). Spectra at 20 and $35 \mathrm{eV}$ were recorded in the GCT spectrometer (Waters) or in a Thermo DSQ II spectrometer. MS/MS analysis were obtained with a triple quadrupole 1200L (Varian, Walnut Creek, CA, USA) associated to a chromatograph Varian 3800. The conditions are: ionizing energy, $70 \mathrm{eV}$; collision gas: argon at a pressure of $2.04 \mathrm{mTorr}$; collision energy: 16v.

Compounds $\mathbf{1 a}, \mathbf{4 a},{ }^{16} \mathbf{1 c}, \mathbf{1 e - \mathbf { g } ^ { 3 \mathrm { d } }}$ and $\mathbf{4 b - d}, \mathbf{g}^{17}$ were synthesized according literature procedures. Preparation and analytical characterization of new compounds are described below. Melting points were taken on a Büchi capillary apparatus and are uncorrected. The ${ }^{1} \mathrm{H}$ - and ${ }^{13} \mathrm{C}-\mathrm{NMR}$ spectra were recorded on a Bruker MSL $300 \mathrm{MHz}$ spectrometer employing TMS as internal reference. Deuteriochloroform or DMSO- $d_{6}$ were used as the solvent, and the standard concentration of the samples for ${ }^{1} \mathrm{H}-\mathrm{NMR}$ was $10 \mathrm{mg} / \mathrm{mL}$ and $25 \mathrm{mg} / \mathrm{mL}$ for ${ }^{13} \mathrm{C}-\mathrm{NMR}$. Chemical shifts are reported in ppm $(\delta)$ relative to TMS as an internal standard. Splitting multiplicities are reported as singlet (s), broad signal (br s), doublet (d), triplet (t), quartet (q), and multiplet (m).

Methyl 3,4-pyridinedicarboximidoacetate (1b). A mixture of 3,4-pyridinedicarboximide (148 mg, $1 \mathrm{mmol})$, triethylamine $(0.56 \mathrm{~mL}, 4 \mathrm{mmol})$, methyl chloroacetate $(0.11 \mathrm{~mL}, 1.2 \mathrm{mmol})$ and DMF (2 $\mathrm{mL})$ was heated for $3 \mathrm{~h}$ in an oil bath $\left(65^{\circ} \mathrm{C}\right)$. The reaction mixture was poured into ice-water and the resulting solid filtered, washed with water and recrystallized. Yield $62 \%$; $\mathrm{mp} 61-63^{\circ} \mathrm{C}$ (from 2propanol); ${ }^{1} \mathrm{H}$ NMR $\delta\left(\mathrm{DCCl}_{3}\right) 9.19$ (s, $\left.1 \mathrm{H}, \mathrm{H}-2\right), 9.11$ (d, $\left.{ }^{3} J_{5,6}=4.6 \mathrm{~Hz}, 1 \mathrm{H}, \mathrm{H}-6\right), 7.82$ (d, ${ }^{3} J_{5,6}=4.6$ $\mathrm{Hz}, 1 \mathrm{H}, \mathrm{H}-5), 4.45$ (s, 2H, $\left.\mathrm{NCH}_{2}\right), 3.78\left(\mathrm{~s}, 3 \mathrm{H}, \mathrm{OCH}_{3}\right) ;{ }^{13} \mathrm{C} \mathrm{NMR} \delta\left(\mathrm{DCCl}_{3}\right)$ 167.1, 166.2 and 165.9 (3 CO), 155.8 (C-6), 145.0 (C-2), 139.3 (C-4), 125.7 (C-3), $117.1(\mathrm{C}-5), 52.8\left(\mathrm{OCH}_{3}\right), 38.9\left(\mathrm{NCH}_{2}\right)$. Anal. Calcd for $\mathrm{C}_{10} \mathrm{H}_{8} \mathrm{~N}_{2} \mathrm{O}_{4}$ : C, 54.55; H, 3.66; N, 12.72. Found: C, 54.61; H, 3.70; N, 12.79 .

$\boldsymbol{\beta}$-(3,4-Pyridinedicarboximido)propionic acid (2a). A mixture of 3,4-pyridinedicarboxylic anhydride (149 mg, $1 \mathrm{mmol}), \beta$-aminopropionic acid (82 $\mathrm{mg}, 1.1 \mathrm{mmol})$ and DMF (2 mL) was 
mantained with stirring for $50 \mathrm{~min}$ at $110^{\circ} \mathrm{C}$. The mixture was cooled, triturated with cold water and then filtered. Yield 80\%; mp 202-204 ${ }^{\circ} \mathrm{C}$ (methanol). ${ }^{1} \mathrm{H}$ NMR $\delta$ (DMSO) 13.02 (bs, $1 \mathrm{H}, \mathrm{OH}$ ), 9.11 (s, $1 \mathrm{H}, \mathrm{H}-2), 9.08$ (d, $\left.{ }^{3} J_{5,6}=4.7 \mathrm{~Hz}, 1 \mathrm{H}, \mathrm{H}-6\right), 7.89$ (d, $\left.{ }^{3} J_{5,6}=4.7 \mathrm{~Hz}, 1 \mathrm{H}, \mathrm{H}-5\right), 3.79$ (t, ${ }^{3} J_{\mathrm{CH} 2-}$ $\left.\mathrm{CH}_{2}=7.3 \mathrm{~Hz}, 2 \mathrm{H}, \mathrm{NCH}_{2}\right), 2.60\left(\mathrm{t},{ }^{3} \mathrm{~J}_{\mathrm{CH} 2-\mathrm{CH} 2}=7.3 \mathrm{~Hz}, 2 \mathrm{H}, \mathrm{CH}_{2} \mathrm{CO}\right) ;{ }^{13} \mathrm{C} \mathrm{NMR} \delta$ (DMSO) 167.5, 166.9 and 163.0 (3 CO), 155.5 (C-6), 147.0 (C-2), 139.5 (C-4), 125.8 (C-3), 119.4 (C-5), 38.2 $\left(\mathrm{NCH}_{2}\right), 33.3\left(\mathrm{CH}_{2} \mathrm{CO}\right)$. Anal. Calcd for $\mathrm{C}_{10} \mathrm{H}_{8} \mathrm{~N}_{2} \mathrm{O}_{4}$ : C, 54.55; H, 3.66; N, 12.72. Found: C, 54.48; $\mathrm{H}, 3.72 ; \mathrm{N}, 12.68$.

Methyl $\boldsymbol{\beta}$-(3,4-pyridinedicarboximido)propionate (2b). To a solution of acid $\mathbf{2 a}(110 \mathrm{mg}, 0.5$ $\mathrm{mmol})$ in anhydrous methanol $(5 \mathrm{~mL})$ an ethereal solution of diazomethane was added in small portions until the solution acquired a pale yellow colour. After $2 \mathrm{~h}$ at room temperature, the reaction mixture was concentrated in vacuo and the crude product was purified by column chromatography (silica gel 60, 0.063-0.200 mesh) eluting with DCM. Yield 32\%; oil; ${ }^{1} \mathrm{H}$ NMR $\left(\mathrm{DCCl}_{3}\right) \delta 9.10(\mathrm{~s}, 1 \mathrm{H}, \mathrm{H}-2), 9.04\left(\mathrm{~d},{ }^{3} J_{5,6}=4.9 \mathrm{~Hz}, 1 \mathrm{H}, \mathrm{H}-6\right), 7.77\left(\mathrm{~d},{ }^{3} J_{5,6}=4.9 \mathrm{~Hz}, 1 \mathrm{H}, \mathrm{H}-5\right)$, $3.99\left(\mathrm{t},{ }^{3} J_{\mathrm{CH} 2-\mathrm{CH} 2}=7.1 \mathrm{~Hz}, 2 \mathrm{H}, \mathrm{NCH}_{2}\right), 3.75\left(\mathrm{~s}, 3 \mathrm{H}, \mathrm{OCH}_{3}\right), 2.70\left(\mathrm{t},{ }^{3} J_{\mathrm{CH} 2-\mathrm{CH} 2}=7.1 \mathrm{~Hz}, 2 \mathrm{H}\right.$, $\left.\mathrm{CH}_{2} \mathrm{CO}\right) ;{ }^{13} \mathrm{C} \mathrm{NMR} \delta\left(\mathrm{DCCl}_{3}\right)$ 167.2, 166.8 and 166.1 (3 CO), $155.8(\mathrm{C}-6), 145.4(\mathrm{C}-2), 138.9$ (C-4), $125.4(\mathrm{C}-3), 117.6(\mathrm{C}-5), 51.7\left(\mathrm{OCH}_{3}\right), 34.1\left(\mathrm{NCH}_{2}\right), 33.2\left(\mathrm{CH}_{2} \mathrm{CO}\right)$. Anal. Calcd for $\mathrm{C}_{11} \mathrm{H}_{10} \mathrm{~N}_{2} \mathrm{O}_{4}$ : C, 56.41; H, 4.30; N, 11.96. Found: C, 56.34; H, 4.35; N, 11.90.

Ethyl $\beta$-(3,4-pyridinedicarboximido)propionate (2c). A mixture of 3,4-pyridinedicarboximide $(146 \mathrm{mg}, 1 \mathrm{mmol})$, ethyl $\beta$-bromopropionate $(0.11 \mathrm{~mL}, 1.1 \mathrm{mmol})$, triethylamine $(0.56 \mathrm{~mL}, 4$ mmol), and DMF ( $2 \mathrm{~mL})$ was heated for $9 \mathrm{~h}$ in an oil bath at $50{ }^{\circ} \mathrm{C}$. The reaction mixture was poured into ice-water and the aqueous layer was extracted with DCM ( 2 x $4 \mathrm{~mL})$. The combined organic layers were dried over anhydrous sodium sulfate. After filtration the solvent was evaporated and the crude product was purified by column chromatography (silica gel 60, 0.063-0.200 mesh) eluting with DCM. Yield 12\%; oil; ${ }^{1} \mathrm{H}$ NMR $\delta\left(\mathrm{DCCl}_{3}\right) 9.15$ (s, $\left.1 \mathrm{H}, \mathrm{H}-2\right), 9.06\left(\mathrm{~d},{ }^{3} J_{5,6}=4.9 \mathrm{~Hz}, 1 \mathrm{H}\right.$, $\mathrm{H}-6), 7.75\left(\mathrm{~d},{ }^{3} J_{5,6}=4.9 \mathrm{~Hz}, 1 \mathrm{H}, \mathrm{H}-5\right), 4.12\left(\mathrm{q},{ }^{3} J_{\mathrm{CH} 2-\mathrm{CH} 3}=7.1 \mathrm{~Hz}, 2 \mathrm{H}, \mathrm{OCH}_{2}\right), 4.03\left(\mathrm{t},{ }^{3} J_{\mathrm{CH} 2-\mathrm{CH} 2}=7.2\right.$ $\left.\mathrm{Hz}, 2 \mathrm{H}, \mathrm{NCH}_{2}\right), 2.72\left(\mathrm{t},{ }^{3} \mathrm{~J}_{\mathrm{CH} 2-\mathrm{CH} 2}=7.2 \mathrm{~Hz}, 2 \mathrm{H}, \mathrm{CH}_{2} \mathrm{CO}\right), 1.20\left(\mathrm{t},{ }^{3} \mathrm{~J}_{\mathrm{CH} 2-\mathrm{CH} 3}=7.1 \mathrm{~Hz}, 3 \mathrm{H}, \mathrm{CH}_{3}\right) ;{ }^{13} \mathrm{C}$ NMR $\delta\left(\mathrm{DCCl}_{3}\right)$ 166.6, 166.3 and 166.1 (3 CO), 156.0 (C-6), 145.1 (C-2), 139.0 (C-4), 125.4 (C-3), $118.2(\mathrm{C}-5), 62.1\left(\mathrm{OCH}_{2}\right), 33.8\left(\mathrm{NCH}_{2}\right), 33.0\left(\mathrm{CH}_{2} \mathrm{CO}\right), 14.1\left(\mathrm{CH}_{3}\right)$. Anal. Calcd for $\mathrm{C}_{12} \mathrm{H}_{12} \mathrm{~N}_{2} \mathrm{O}_{4}$ : C, 58.06; H, 4.87; N, 11.28. Found: C, 57.98, H, 4.92; N, 11.21.

Ethyl $\gamma$-(3,4-pyridinedicarboximido)butyrate (3c). This compound was obtained employing similar method to described above for compound 2c using ethyl $\gamma$-bromobutyrate $(0.15 \mathrm{~mL}, 1.1$ mmol) and heating at $60{ }^{\circ} \mathrm{C}$ for $3 \mathrm{~h}$. Yield 38\%; oil; ${ }^{1} \mathrm{H}$ NMR $\delta\left(\mathrm{DCCl}_{3}\right) 9.16(\mathrm{~s}, 1 \mathrm{H}, \mathrm{H}-2), 9.10(\mathrm{~d}$, $\left.{ }^{3} J_{5,6}=4.9 \mathrm{~Hz}, 1 \mathrm{H}, \mathrm{H}-6\right), 7.79\left(\mathrm{~d},{ }^{3} J_{5,6}=4.9 \mathrm{~Hz}, 1 \mathrm{H}, \mathrm{H}-5\right), 4.24\left(\mathrm{t},{ }^{3} J_{\mathrm{CH} 2-\mathrm{CH} 2}=7.7 \mathrm{~Hz}, 2 \mathrm{H}, \mathrm{NCH}_{2}\right), 4.08$ $\left(\mathrm{q},{ }^{3} J_{\mathrm{CH} 2-\mathrm{CH} 3}=7.1 \mathrm{~Hz}, 2 \mathrm{H}, \mathrm{OCH}_{2}\right), 2.43\left(\mathrm{t},{ }^{3} J_{\mathrm{CH} 2-\mathrm{CH} 2}=7.7 \mathrm{~Hz}, 2 \mathrm{H}, \mathrm{CH}_{2} \mathrm{CO}\right), 2.10\left(\mathrm{~m},{ }^{3} J_{\mathrm{CH} 2-\mathrm{CH} 2}=7.7\right.$ $\left.\mathrm{Hz}, 2 \mathrm{H}, \mathrm{CH}_{2}-\mathrm{CH}_{2}-\mathrm{CH}_{2}\right), 1.21\left(\mathrm{t},{ }^{3} \mathrm{~J}_{\mathrm{CH} 2-\mathrm{CH} 3}=7.1 \mathrm{~Hz}, 3 \mathrm{H}, \mathrm{CH}_{3}\right) ;{ }^{13} \mathrm{C} \mathrm{NMR} \delta\left(\mathrm{DCCl}_{3}\right) 167.2,166.8$ and 166.0 (3 CO), 155.5 (C-6), 144.6 (C-2), 139.5 (C-4), 125.9 (C-3), 116.7 (C-5), $62.0\left(\mathrm{OCH}_{2}\right), 37.6$ $\left(\mathrm{NCH}_{2}\right), 34.3\left(\mathrm{CH}_{2} \mathrm{CO}\right), 30.6\left(\mathrm{CH}_{2}-\mathrm{CH}_{2}-\mathrm{CH}_{2}\right), 13.7\left(\mathrm{CH}_{3}\right)$. Anal. Calcd for $\mathrm{C}_{13} \mathrm{H}_{14} \mathrm{~N}_{2} \mathrm{O}_{4}$ : C, 59.54; H, 5.38; N, 10.68. Found: C, 59.47, H, 5.42; N, 10.61 .

Mass and relative abundance of characteristic ions of compounds 1a-f, $\mathbf{2 a - c}$ and $\mathbf{4 b}$-d are presented in Tables 1-4. Data for compound 3c are depicted in Scheme 7. 
MS of compound (1g). $(70 \mathrm{eV}): \mathrm{m} / z(R A \%) 266\left(\mathrm{M}^{+*}, 3\right), 161\left(\mathbf{A}^{+}, 6\right), 105\left(\mathrm{PhCO}^{+}, 100\right), 77\left(\mathrm{Ph}^{+}\right.$, 56), $51\left(\mathrm{C}_{4} \mathrm{H}_{3}{ }^{+}, 26\right)$.

MS of compound (4g). (70 eV): m/z (RA \%) $266\left(\mathrm{M}^{+\cdot}, 6\right), 238\left(\mathrm{M}^{++}-\mathrm{CO}, 2\right), 161\left(\mathbf{A}^{+}, 6\right), 105$ $\left(\mathrm{PhCO}^{+}, 100\right), 77\left(\mathrm{Ph}^{+}, 76\right), 51\left(\mathrm{C}_{4} \mathrm{H}_{3}{ }^{+}, 30\right)$.

HRMS of 3,4-pyridinedicarboximide. $m / z(R A \%) 148.0271(100 \%)$, [M] ${ }^{++}$, calcd for $\mathrm{C}_{7} \mathrm{H}_{4} \mathrm{~N}_{2} \mathrm{O}_{2}$ : 148.0273; 105.0222 (59), [M-HNCO ] ${ }^{+*}$, calcd for $\mathrm{C}_{6} \mathrm{H}_{3} \mathrm{NO}: 105.0215 ; 77.0267$ (39), [M-HNCO$\mathrm{CO}]^{+*}$, calcd for $\mathrm{C}_{5} \mathrm{H}_{3} \mathrm{~N}$ : $77.0265 ; 50.0170$ (34), [M-HNCO-CO-HCN] ${ }^{+}$, calcd for $\mathrm{C}_{4} \mathrm{H}_{2}: 50.0157$.

HRMS of $N$-methyl-3,4-pyridinedicarboximide. $\mathrm{m} / z$ (RA\%) $162.0434(100),[\mathrm{M}]^{+\cdot}$, calcd for $\mathrm{C}_{8} \mathrm{H}_{6} \mathrm{~N}_{2} \mathrm{O}_{2}: 162.0429 ; 161.0371(2)$, $[\mathrm{M}-\mathrm{H}]^{+}$, calcd for $\mathrm{C}_{8} \mathrm{H}_{5} \mathrm{~N}_{2} \mathrm{O}_{2}: 161.0351 ; 133.0390$ (3), [M-H$\mathrm{CO}^{+}$, calcd for $\mathrm{C}_{7} \mathrm{H}_{5} \mathrm{~N}_{2} \mathrm{O}: 133.0402 ; 118.0534(8)$, $\left[\mathrm{M}_{-}-\mathrm{CO}_{2}\right]^{+*}$, calcd for $\mathrm{C}_{7} \mathrm{H}_{6} \mathrm{~N}_{2}$ : 118.0531; 106.0290 (5), [M-HCN-CO] ${ }^{+*}$, calcd for $\mathrm{C}_{6} \mathrm{H}_{5} \mathrm{NO}: 106.0293 ; 105.0230$ (23), [M-MeNCO$]^{++}$, calcd for $\mathrm{C}_{6} \mathrm{H}_{3} \mathrm{NO}$ : 105.0215; 77.0270 (17), [M-MeNCO-CO $]^{+*}$, calcd for $\mathrm{C}_{5} \mathrm{H}_{3} \mathrm{~N}$ : 77.0265 .

\section{Acknowledgements}

This work was financially supported by the Buenos Aires University.

\section{References and Notes}

1. Among others: (a) Bentley, T. W.; Johnstone, R. A. W. J. Chem. Soc. (C) 1968, 2354. (b) Aplin, R. T.; Jones, J. H. J. Chem. Soc. (C) 1968, 1770. (c) Blanc, P. A.; Gülaçar, F. O.; Buchs, A. Helv. Chim. Acta 1979, 62, 2230. (d) Weisz, A.; Andrzejewski, D.; Mandelbaum, A. J. Mass Spectrom. 1996, 31, 676. (e) Denitz, J.; Monteiro, B. D. A.; Ramos, M. N. Srivastava, R. M.. Heterocyclic Commun. 1997, 3, 115.

2. Blanco, M. M.; Perillo, I. A. Heterocycles 2008, 75, 305.

3. Among others: (a) Hamprecht, G.; Goetz, N.; Wuerzer, B.; Westphalen, K.-O. Eur. Pat. 0422 456 B1, 1991; Chem. Abstr. 1991, 115, 92084. (b) Paul, D. B.; Rodda, H. J. Aust. J. Chem. 1968, 21, 1291. (c) Delaine, T.; Bernardes-Génisson, V.; Meunier, B.; Bernadou, J. J. Org. Chem. 2007, 72, 675 and references cited therein. (d) Perillo, I. A.; Kremenchuzki, L. D.; Blanco, M. M. J. Mol. Struct. 2009, 921, 307.

4. Among others: (a) Bailleux, V.; Vallée, L.; Nuyts, J. P.; Vamecq, J. Biomed. \& Pharmacother. 1995, 49, 75. (b) Śladowska, H.; Filipek, B.; Szkatula, D.; Sapa, J.; Bednarski, M.; Ciolkowska, M. Il Farmaco 2005, 60, 53 and references cited therein. c) Muszalska, I.; Wojtyniak, E. Acta Pol. Pharm. Drug Research 2007, 64, 319 and references cited therein. d) Hulin, B.;Parker, J. C.; Piotrowski, D. U. S. Patent 234 065, 2005; Chem. Abstr. 2005, 143, 406151.

5. Budzikiewicz, H.; Djerassi C.; Williams, D. H. In Mass Spectrometry of Organic Compounds, Holden-Day, Inc., 1967; p 363.

6. We confirmed the data reported by Johnstone ${ }^{1 \mathrm{a}}$ and determined the composition of the main peaks by HRMS (see Experimental Section). 
7. Relative abundances of $\mathrm{m} / \mathrm{z} 162$ ion at 70 and $20 \mathrm{eV}$ using a CGT Waters spectrometer: $47 \%$ and $97 \%$ respectively).

8. In our previous work ${ }^{2}$ based on HRMS data, it was considered that the main degradation pathway of ion at 134 (B'-CO) involved the loss of $\mathrm{CH}_{2}=\mathrm{NH}$ leading to an ion at $\mathrm{m} / \mathrm{z} 105$ $\left(\mathrm{C}_{6} \mathrm{H}_{3} \mathrm{NO}\right)$. This must now be rectified in the light of MS/MS experiments performed lately and presented in the present work, which demonstrate that the main transformation of $\mathrm{m} / \mathrm{z} 134$ ions leads to ion $\mathrm{m} / z 79\left(\mathrm{C}_{5} \mathrm{H}_{5} \mathrm{~N}\right)$ (corresponding to pyridine odd electron ion). Ion at $\mathrm{m} / z \quad 105$ $\left(\mathrm{C}_{6} \mathrm{H}_{3} \mathrm{NO}\right)$ and those derived from it $(\mathrm{m} / \mathrm{z} 77$ and 50) are common in this type or pyridine derivatives. They may have multiple origins and probably arise from another fragmentation pathway of $\mathrm{M}^{+\cdot}$.

9. MS of compound 1c at $20 \mathrm{eV}$ using a Thermo DSQ II spectrometer: $m / z(R A \%) 234$ (77), 206 (5), 189 (27), 162 (100), 161 (63), 134 (30), 106 (13), 105 (15), 78 (12).

10. Relative abundances $(R A \%)$ of select ions at 70,35 and $20 \mathrm{eV}$ using a CGT Waters spectrometer: $\mathrm{m} / \mathrm{z} 162(20,36$ and $77 \%$ respectively), $\mathrm{m} / \mathrm{z} 134(5,7$ and 20\% respectively) and $m / z 79(8,12$ and $16 \%$ respectively).

11. McLafferty, F. W.; Tureček, F. In Interpretation of Mass Spectra, University Science Books, 1993; p 77.

12. Selim, E. T. M.; Rabbih, M. A.; Fahmey, M. A. Org. Mass Spectrom. 1992, 27, 919.

13. Harpp, D. N.; Back, T. G. J. Org. Chem. 1973, 38, 4328.

14. Bentley, T. W.; Johnstone, R. A. W. J. Chem. Soc. (B) 1971, 1804

15. MS/MS experiment shows the presence of $\mathrm{m} / \mathrm{z} 131$ ion as product of $\mathrm{m} / \mathrm{z}, 148$ and allows us to discard the alternative structure of 3,4-pyridinedicarboximide radical ion (see Experimental Section).

16. Lee, F. C.; Caswell, L. R. J. Heterocycl. Chem. 1971, 8, 831

17. Blanco, M. M.; Lorenzo, M. G.; Perillo, I. A.; Schapira, C. B. J. Heterocycl. Chem. 1996, 33, 361. 